\title{
DETERMINATION OF THE POTENTIAL BIODIESEL VOLUME OF SOYBEAN USED AS THE FIRST-GENERATION BIODIESEL FEEDSTOCK IN THE UNITED STATES
}

\author{
Hülya KARABAȘ ${ }^{*}$ \\ ${ }^{1}$ Sakarya University, Faculty of Engineering, Department of Environmental Engineering, 54187, Sakarya, Turkey
}

\begin{abstract}
In the United States (U.S), biodiesel is produced from vegetable oils, animal fats, recycled restaurant oil, and waste oil. Soybean oil has been by far the most widely used feedstock for U.S biodiesel production, accounting for more than half of the nation's biodiesel feedstock. This study aimed to determine the potential biodiesel volume of the soybean plant, which is the most cultivated product as a first-generation biodiesel feedstock in the U.S. The potential biodiesel volume of the soybean plant, which was grown on an area of 30352150 hectares in the U.S in 2019, was calculated as 1020749343 liters. Biofuels can be produced domestically, which could lead to lower fossil fuel imports. As in the rest of the world, if the production and use of biofuels in the U.S reduce imported fossil fuel consumption, it may become less vulnerable to its adverse effects in terms of energy supply security. Reducing demand for petroleum could also reduce its price, generating economic benefits for U.S consumers. Knowing the potential of oilseed plants used as feedstocks in first-generation biodiesel production will accelerate efforts to identify products that should be used in second-generation biodiesel production and expand their cultivation. Studies should be planned to remove the threat on the food sector by replacing the first-generation biodiesel production feedstocks, which are mainly used as oil feedstocks in the food sector, with the second-generation inedible oil feedstocks that are not used in the food sector.
\end{abstract}

Keywords: Biodiesel volume, Soybean plant, Oil seed, Feedstock

*Corresponding author: Sakarya University, Faculty of Engineering, Department of Environmental Engineering, 54187, Sakarya, Turkey

E mail: hkarabas@sakarya.edu.tr (H. KARABAŞ)

$\begin{array}{llll}\text { Hülya KARABAȘ (iD) https://orcid.org/0000-0002-2773-6160 } & \text { Received: July 12, } 2021\end{array}$

Accepted: August 08, 2021

Published: October 01, 2021

Cite as: Karabaş H. 2021. Determination of the potential biodiesel volume of soybean used as the first-generation biodiesel feedstock in the United States. BSJ Agri, 4(4): 119-123.

\section{Introduction}

Different biofuel feedstock sources and production processes have many other impacts, including greenhouse gas emissions, life cycle, air pollutants, land and water use. Therefore, policies on biofuel production and use are directly affected by this situation. Both biofuel technologies and other alternative power train technologies will determine the volume of biofuels and what types of transportation fuels they can integrated them. For the efficient integration of biofuels into the transport fuels market, must coordinate production, transport, distribution, and automobile infrastructure (Mishra and Goswami, 2018; Elgharbawy et al., 2021).

First-generation biofuels are made from sugar crops (sugarcane, sugar beet), starch crops (corn, sorghum), oilseed crops (soybean, canola), and animal fats. Oils and animal fats can be processed into biodiesel. Secondgeneration biofuels, or cellulosic biofuels, are made from cellulose, available from non-food crops and waste biomass such as corn stover, straw, wood, and wood byproducts. Third-generation biofuels use algae as a feedstock. Commercial cellulosic biofuel production began in the U.S in 2013, while algae biofuels are not yet produced commercially (Huang et al., 2013).
Several laws and regulations at the federal, state, and local levels have been essential drivers of biofuel production and use in the U.S. The Environmental Protection Agency (EPA) has implemented mandates for how much renewable fuel must be blended with fossil fuels Renewable Fuel Standard (RFS) mandate was passed in 2005, and in 2007, an expanded mandate, known as RFS2, was passed to include cellulosic biofuels. The Renewable Fuels Standard (RFS2) requires an increase in biofuel use, which should nearly triple from 13.6 billion gallons per year to 36 billion gallons per year by 2022 . According to RFS2, it is recommended to meet $90 \%$ of this amount from cellulosic biofuels and advanced biomass-based diesel.

In Figure 1, the energy resources of the United States, ranging from the 1700 s to the present, are shown. As of $2020,79 \%$ of the country's energy needs are met from fossil fuels and $21 \%$ from renewable energy sources and biofuels (EIA, 2021). In Figure 2, the usage rates of each of the renewable energy sources in U.S in 2020 and the sectors in which these sources are used are given (EIA, 2021). 


\section{Black Sea Journal of Agriculture}

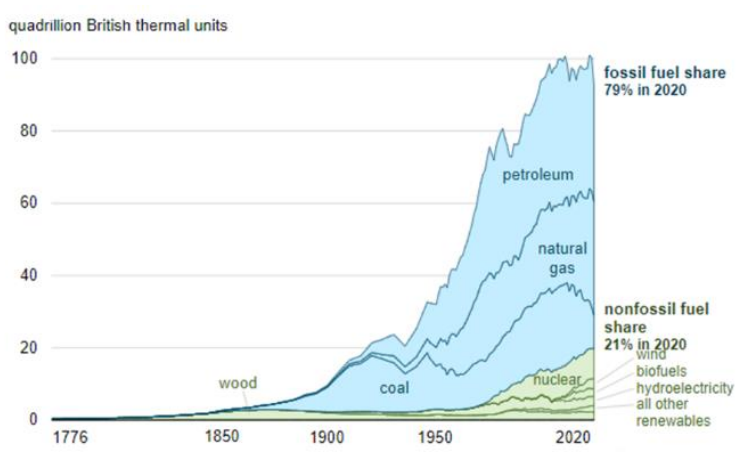

Figure 1. Energy consumption in the United States (1776-2020).

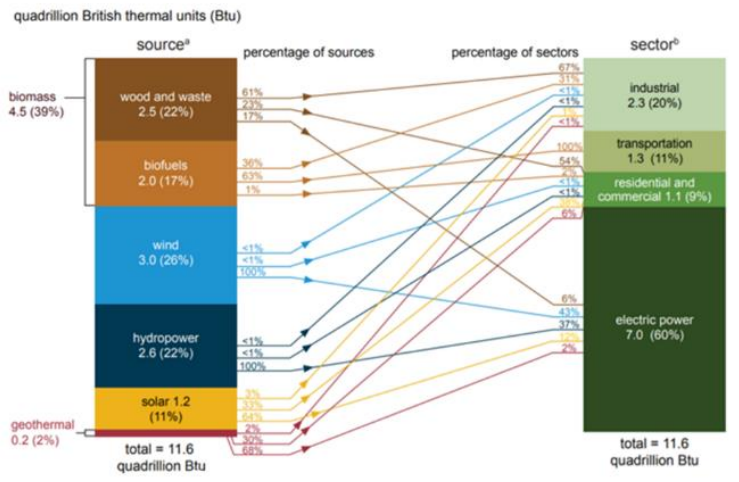

Figure 2. U.S. Renewable Energy consumption by source and sector.

According to the U.S Energy Information Administration (EIA) Annual Energy Report in 2021, renewable energy consumption in the United States increased for the fifth consecutive year, reaching 11.6 quadrillion British thermal units (Btu), accounting for $12 \%$ of U.S energy consumption. While renewable energy production increased, fossil fuel and nuclear energy consumption decreased.

Biodiesel is an alkyl ester produced from renewable raw materials such as vegetable oils, animal fat, and algae. Biodiesel is one of the biofuels used in large quantities and widely in the U.S, Brazil, Indonesia, Malaysia, France, Germany and other European countries. High cetane number, clean combustion, good lubrication, low aromatic content, low sulfur content, and low pour point are the main features of biodiesel that make it superior to petrodiesel (Agarwal, 2007; Singh and Singh, 2010; Moser, 2016; Živković and Veljković, 2018). In addition, the distinguishing features of biodiesel are that it reduces particulate matter (PM), carbon monoxide (CO), and hydrocarbon (HC) emissions in exhaust gas. Therefore, biodiesel is an environmentally friendly fuel (Mishra and Goswami, 2018; Rouhany and Montgomery, 2019; Elgharbawy et al., 2021).

A century ago, the soybean was practically unknown outside Asia. Today, hundreds of millions of people worldwide eat meat, eggs, and dairy products from animals fed on soy, and traces of soybean are found in countless processed foods. In the last 50 years, the production of soybean has grown tenfold, from 27 to 269 million tons. The total soybean area now covers over 1 million square kilometers - the total combined region of France, Germany, Belgium, and the Netherlands. This expansion shows no sign of stopping: the United Nations Food and Agriculture Organization (FAO) suggests soybean production will almost double by 2050 . Markets in Africa and the Middle East are also expected to expand rapidly in the next decade.

Soybeans are grown throughout much of North America, South America, and Asia. In other words, soybeans are a global food crop. According to National Agriculture Statistics Service (NASS, 2021)'s statements The United States produces roughly $32 \%$ of all soybeans globally, followed by Brazil at 28\%. Despite its relatively high price as a food crop, soybean is still a significant feedstock for biofuel production.

The use of soybean oil for biodiesel was greatly influenced by promotion from U.S. soybean farmers through the United Soybean Board (USB) and the subsequent creation of the National Biodiesel Board (NBB). Soybeans account for $80 \%$ or more of the edible fats and oils consumed in the U.S. Soybean oil is mainly used for food consumption and, more recently, for other uses such as biodiesel. Combined, soybeans and their derivatives are the most traded agricultural commodity, accounting for over $10 \%$ of the total value of global agricultural trade. Global trade in soybeans and soybean products has risen rapidly since the early 1990s and, in $2008 / 2009$, surpassed international trade of wheat and total coarse grains (Pradhan et al., 2009; Huang et al., 2013). According to USDA Agricultural Projections, by 2025 , world trade is projected to increase in soybeans by $22 \%$, soybean meal by $20 \%$, and soybean oil by $30 \%$.

Soybean was the most produced oilseed crop in the world in the 2018-2019 sowing season, followed by rapeseed, sunflower, peanut, and cotton, respectively. The total amount of oilseed production in the world in the 2018-2019 season was 599.7 million tons. Three hundred fifty million tons of this belongs to the soybean plant. In the same production season, the country with the largest soybean production in the world was U.S (120.5 million tons), followed by Brazil (119.7 million tons), Argentina (55.3 million tons), China (15.9 million tons), and India (10.9 million tons). In this period, soybean production in Europe was 2.6 million tons. Figure 3 shows the increase in soybean production in the world and in the United States over the years (FAOSTAT, 2021).

While soybean production in the world was 20-30 million tons annually in the 1960s, the amount of production increased over the years and reached 350 million tons in the 2018-2019 production season. In this season, the production amount in U.S, the largest soybean producer globally, was 124 million tons (USDA, 2018; USDA, 2020). The diversity of biodiesel feedstock has led to a broader geographical distribution of biodiesel 


\section{Black Sea Journal of Agriculture}

refineries. Figure 4 shows the locations of ethanol and biodiesel refineries currently produced in the U.S.

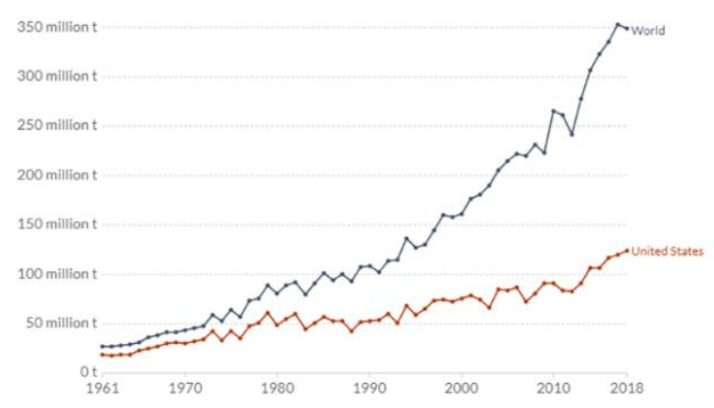

Figure 3. Soybean production amounts in the world and U.S.

Biodiesel refineries are, for similar reasons, located in close proximity to feedstock supplies, although the feedstocks used to produce biodiesel vary a great deal more than for ethanol. Biodiesel feedstocks include soybean oil, other vegetable oils, and animal fats, the latter typically byproducts from food production or preparation. The variability of biodiesel feedstocks has led to a wider geographic distribution of biodiesel refineries. Figure 4 shows the locations of ethanol and biodiesel refineries currently producing in the United States.

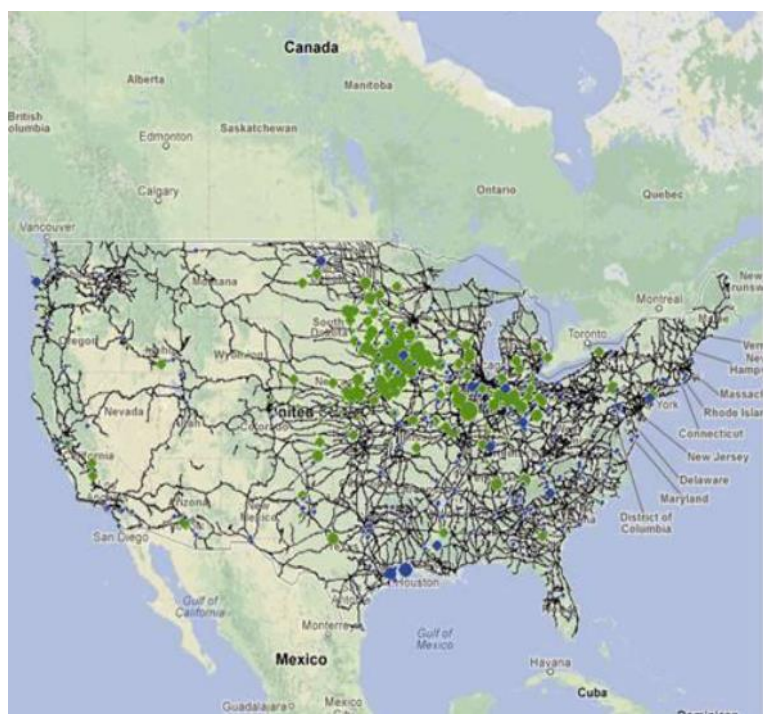

Figure 4. Locations of refineries producing biodiesel and ethanol in the U.S.

The blue dots on the map show the locations of the biodiesel refineries, and the green ones show the locations of the ethanol refineries. Biodiesel production in the U.S emerged in the early 2000s due to the need for energy independence and growing concern about reduced greenhouse gas emissions. As shown in Figure 4, production facilities are spread over a wide geographical area of the country. The top four states in biodiesel production capacity are Texas, Iowa, Illinois, and
Missouri, respectively. These four states have more than half of the U.S production capacity. Texas has a large oil refining capacity that fits well with the need to blend biodiesel with petroleum-based diesel fuel. Three of the top four states are located in the center of the country's Soybean Belt and have significant sources of soybean oil for biodiesel production.

The feedstock is an essential element in the biodiesel industry, as feedstock costs make up the bulk of biodiesel. Today, the feedstock equates to at least $80 \%$ of the expenses associated with biodiesel production. Approximately $95 \%$ of the biodiesel production in the world is made from cooking oils, and it is seen as an unnecessary situation when the world has a food problem. Each country should prefer feedstocks with high oil yields, which can be grown at a low cost by their geographical and climatic conditions in biodiesel production (Mishra and Goswami, 2018).

The EIA, 2021 report provides monthly data on the number of different feedstocks used for biodiesel production. Soybean oil was the dominant feedstock accounting for more than half of the total feedstock used in the biodiesel industry in 2010 and 2020. Other feedstocks include canola oil, tallow, poultry oils, yellow grease, white grease, and a minimal amount of corn oil. Yellow grease is a term for recycled cooking oils. The main reasons soybean oil is preferred as an oil feedstock in biodiesel production are its abundant source and suitable fatty acid profile. More than 90 million acres of soybeans were planted in the United States in 2017, and in 2018, the acres planted for soybeans exceeded corn acreage for the first time since 1983. Soybean acreage fell to 76.1 million acres in 2019 (USDA, 2020). The United States is the world's largest producer of soybeans. Exports of oilseeds, especially soybeans, are an essential source of demand for U.S producers and make an enormous net contribution to the U.S agricultural trade balance.

This study aimed to determine the potential biodiesel volume of the soybean plant, which is produced in the highest amount as the first-generation feedstock in biodiesel production in the U.S.

\section{Material and Methods}

In this study, soybean was investigated as the oilseed plant with the largest cultivation area in America and globally. Data were taken from the public, online sources. Food and Agriculture Organization (FAO) of the United Nations Statistics Division (FAOSTAT) and U.S. Department of Agriculture (USDA) were used as the source. All biodiesel volumes is based on processed oils and fats export statistics from FAOSTAT 2021.

\subsection{First-Generation Biodiesel Feedstock of the U.S}

Table 1 shows the sources used in renewable energy production in the U.S between 2015 and 2018 and their usage amounts. In 2018, energy consumption from biofuels in the country totaled 2.283 quadrillion Btu. 
Black Sea Journal of Agriculture

Table 1. U.S Renewables consumption and sources

\begin{tabular}{lcccc}
\hline $\begin{array}{c}\text { Energy Sources } \\
\text { (Quadrillion Btu) }\end{array}$ & 2015 & 2016 & 2017 & 2018 \\
\hline Hydroelectric & 2.321 & 2.472 & 2.767 & 2.667 \\
power & 0.212 & 0.210 & 0.210 & 0.209 \\
Geotermal & 0.427 & 0.570 & 0.777 & 0.917 \\
Solar & 1.777 & 2.096 & 2.343 & 2.486 \\
Wind & 2.312 & 2.224 & 2.278 & 2.360 \\
Wood biomass & 2.153 & 2.287 & 2.304 & 2.283 \\
Biofuels & 0.518 & 0.503 & 0.495 & 0.487 \\
Waste biomass & 9.720 & 10.362 & 11.173 & 11.409 \\
TOTAL & & & & \\
\hline
\end{tabular}

Figure 5 shows the proportions of plants used as firstgeneration biodiesel feedstock based on the amount of oil extracted in North and South America. While soybean oil production is $84 \%$, especially in South America, this rate is $19 \%$ in North America. In North America, the major biodiesel feedstock is rapeseed with a proportion of $50 \%$ (Chong et al., 2021).

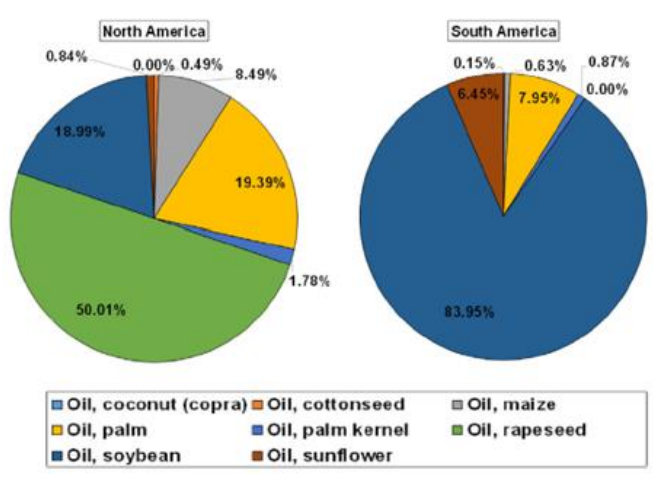

Figure 5. Proportion of potential first-generation feedstock at continental level for North and South America.

\subsection{Potential Biodiesel Volume Calculations}

The potential biodiesel volume (PBV) for soybean feedstock was calculated using the equation 1 and 2 .

$\mathrm{PBV}=\mathrm{LV} \times \mathrm{CR}$

$L V=\frac{E Q \times 1000}{O D}$

where LV is the lipid volume of soybean seed biodiesel feedstocks in U.S, and CR (0.98) is the volumetric conversion ratio from oil to biodiesel. EQ is the export quantity of feedstock, and OD is the oil density (Johnston and Holloway, 2007; Chong et al., 2021). A minimum threshold value of 10000 tons has been set for the export quantity. Any export quantity of vegetable oils lower than the threshold is considered inadequate for potential biodiesel production. The threshold value is based on a generic biodiesel plant with a capacity of 10 million liters per annum. The export quantity which reaches the threshold value is used in the calculation of the potential biodiesel production (USDA, 2017; Chong et al., 2021).

\section{Results}

Soybean, rapeseed, and palm take the first three places as the first-generation feedstocks sources in biodiesel production in the U.S. Table 2 shows the oil and fuel properties of soybean plant.

Table 2. Vegetable oil and fuel properties of soybean plant

\begin{tabular}{ccc}
\hline & Soybean & References \\
\hline Oil content (wt\%) & 17.5 & $\begin{array}{c}\text { Agarwal (2007), } \\
\text { Altın et al. (2001), } \\
\text { Karmakar et al. }\end{array}$
\end{tabular}

Sinha et al. (2008),

Oil density (kg/L) $\quad 0.914 \quad$ Altın et al. (2001),

Karmakar et al. (2010)

Energy content

$(\mathrm{Mj} / \mathrm{kg})$

39.62

Altın et al. (2001),

Biodiesel density

(kg/L)

0.885

Cetane number

Kinematic

viscosity $\left(\mathrm{mm}^{2} / \mathrm{s}\right)$

4

Oxygen content (wt\%) Karmakar et al.

Chong et al. (2021),

Viola et al. (2011)

Giakoumis (2013),

Chong et al. (2021)

Chong et al. (2021),

Viola et al. (2011)

Chong et al. (2021),

Giakoumis (2013)

In 2019, soybean harvest was carried out with a yield of $31890 \mathrm{~kg} / \mathrm{ha}$ in 30352150 hectares in U.S. At the end of this harvest, obtained 96793180 tons of products. Table 3 shows the change in the export quantity amount of soybean oil in the U.S between 2015 and 2019. The lowest soybean oil export quantity these years was in 2019 (FAOSTAT, 2021).

Table 3. Export quantity of soybean oil in U.S

\begin{tabular}{lc}
\hline Years & Export Quantity (tons) \\
\hline 2015 & 958146 \\
2016 & 1004075 \\
2017 & 1069627 \\
2018 & 1105423 \\
2019 & 952005 \\
\hline
\end{tabular}

Table 4 shows the statistical and computational values of the parameters used to calculate the potential biodiesel volume of the soybean feedstock that the U.S operates in the first place in biodiesel production. Equations 1 and 2 were used in the calculations.

\section{Conclusion}

There are four main factors limiting biodiesel production, in general, all over the world. These factors are water stress, food stress, feedstock quantity, and crude oil price. 


\section{Black Sea Journal of Agriculture}

Table 4. Statistical and computational values of soybean feedstock for potential biodiesel volume

\begin{tabular}{lccccc}
\hline Feedstock & PQ (tons) & EQ (tons) (2019) & OD (kg/L) & LV & PBV (L) \\
\hline Soybean & 96793180 & 952005 & 0.914 & 1041580963 & 1020749343 \\
\hline
\end{tabular}

$\mathrm{PQ}=$ production quantity, $\mathrm{EQ}=$ export quantity, $\mathrm{OD}=$ oil density, $\mathrm{LV}=$ lipid volume, $\mathrm{PBV}=$ potential biodiesel volume

In this study, the potential biodiesel volume of the U.S, which is the country that produces the most soybean crops in the world, was determined. While the total soybean harvest amount in the world was 350 million tons in the 2018-2019 sowing season, 124 million tons of this amount belongs to the U.S. With the calculations made, the potential biodiesel volume of the soybean plant in the U.S was found to be 1020749343 liters. Soybean can three categories (direct human food, animal feed, and industrial processes) be used. According to the data of the University of Oxford's Food Climate Research Network (FCRN), the industrial usage rate of soybean in the world is $4 \%$. The share of use only for biodiesel production at this rate is $2.8 \%$. The remainder are used as lubricants and in other industrial processes. In this respect, since the amount of soybean used for energy production is limited, there is no threat to the food sector. The primary factor limiting the potential biodiesel production in the U.S will be feedstock quantity. It can say feedstock quantity and crude oil price will be the factors that restrict biodiesel production globally, and biodiesel sustainability will be primarily interrupted by water stress.

\section{Author Contributions}

All task made by single author and the author reviewed and approved the manuscript.

\section{Conflict of Interest}

The author declared that there is no conflict of interest.

\section{References}

Agarwal AK. 2007. Biofuels (alcohols and biodiesel) applications as fuels for internal combustion engines. Prog Energy Combust Sci, 33(3): 233-271.

Altın R, Cetinkaya S, Yucesu, H. 2001. Potential of using vegetable oil fuels as fuel for diesel engines. Energy Convers Manage, 42: 529-538.

Chong CT, Loe TY, Wong, KY, Ashokkumar V, Lam SS, Chong WT, Borrion A, Tian B, Han NGL. 2021. Biodiesel sustainability: The global impact of potential biodiesel production on the energy-water-food (EWF) nexus. Environ Technol Innov, 22: 101408.

EIA. 2021. The Energy Information Administration, Montly Biodiesel Report. URL: http://www.eia.gov (accessed date: May 25, 2021).

Elgharbawy AS, Sadik WA, Sadek OM., Kasaby A. 2021. A Rewiew on biodiesel feedstocks and production technologies. J Chilean Chem, 66(1): 5098-5109.

FAOSTAT. 2021. The United Nations: Food and Agriculture Organization of the United Nations. URL: http://www.fao.org/faostat/en/\#data/TP (accessed date: June 10, 2021).
Giakoumis EG. 2018. Analysis of 22 vegetable oils' physicochemical properties and fatty acid composition on a statistical basis, and correlation with the degree of unsaturation. Renew Energy, 126: 403-419.

Huang H, Khanna M, Onal H, Chen X. 2013. Stacking low carbon policies on the renewable fuels standard: Economic and greenhouse gas implications. Energy Policy, 56: 5-15.

Johnston M, Holloway T. 2007. Policy analysis a global comparison of national biodiesel production potentials. Environ Sci Technol, 41(23): 7967-7973.

Karmakar A, Karmakar S, Mukherjee S. 2010. Properties of various plants and animals feedstocks for biodiesel production. Bioresour Technol, 101(19): 7201-7210.

Mishra VK, Goswami R. 2018. A review of production, properties and advantages of biodiesel. Biofuels, 9(2): 273289.

Moser BR. 2016. Fuel property enhancement of biodiesel fuels from common and alternative feedstocks via complementary blending. Renew Energy, 85: 819-825.

NASS. 2021. (National Agriculture Statistics Service) URL: http: //www.nass.usda.gov (accessed date: August 04, 2021).

Pradhan A, Shrestha DS, McAloon A, Yee W, Haas M, Duffield JA, Shapouri H. 2009. Energy life-cycle assessment of soybean biodiesel. Agricultural Economic Report, No: 845, Washington, USA, Office of the Chief Economist, Office of Energy Policy and New Uses. www.usda.gov/oce/reports/energy/ELCAofSoybeanBiodiese 191409.pdf. (accessed date: August 04, 2021).

Rouhany M, Montgomery H. 2019. Biodiesel production: The state of the art and impact on climate change, in Biodiesel. Springer, Newyork, USA, 1th ed., pp. 1-14.

Singh SP, Singh D. 2010. Biodiesel production through the use of different sources and characterization of oils and their esters as the substitute of diesel: A review. Renew Sustain Energy Rev, 14(1): 200-216.

Sinha S, Agarwal AK, Garg S. 2008. Biodiesel development from rice bran oil: Transesterification process optimization and fuel characterization. Energy Convers. Manage, 49(5): 12481257.

USDA. 2017. "Foreign Agricultural Service", U.S. Department of Agriculture Gain Report. URL: https://apps.fas.usda.gov/newgainapi/api/report (accessed date: May 18, 2021).

USDA. 2018. Foreign Agricultural Service, Biofuels Annual The Hague EU-28 7-3. URL: https://apps.fas.usda.gov/newgainapi/api/report (accessed date: May 18, 2021).

USDA. 2020. Foreign Agricultural Service, U.S. Department of Agriculture Gain Report. URL: https://apps.fas.usda.gov (accessed date: May 18, 2021).

Viola E, Zimbardi F, Valerio V. 2011. Graphical method to select vegetable oils as potential feedstock for biodiesel production. Eur J Lipid Sci Technol, 113(12): 1541-1549.

Živković S, Veljković M. 2018. Environmental impacts the ofproduction and use of biodiesel. Environ Sci and Pollut Res, 25(1): 191-199. 